\title{
Intelligence and ambition are distributed equally around the globe
}

Kuan-Teh Jeang

\section{Abstract}

The impact of freely accessible knowledge distribution platforms is briefly discussed.

At a recent international conference, I heard former United States president Bill Clinton speak. As a part of his remarks, Clinton commented that in his visits to many developing countries around the world he has found that "The distribution of intelligence and ambition around the world is equal, but the access to opportunities is not" (my paraphrasing). Clinton's point echoes a message of Malcolm Gladwell's book "Outliers"; both argue that a critical key to success is less about who you are or where you are, but whether you have (not) access to the same opportunities as others.

Open Access publishing is fundamentally about providing opportunities (i.e. knowledge) to all in an equally accessible platform. I have noted previously that this principle, beyond all else, was the prime motivation for founding Retrovirology [1]. While the Open Access publishing movement and its egalitarian approach to knowledge dissemination are laudable, one should not neglect to highlight other equally worthy efforts to distribute knowledge freely. One such remarkable project is the MIT OpenCourseWare (OCW) initiative http://ocw.mit. edu) which provides free access via the internet to the academic contents (video lectures, syllabus, problem sets, exam solutions...) of approximately 2,000 courses taught by 33 academic departments. There is an immense demand for OpenCourseWare as evidenced that it is being accessed 1.5 million times each month by nearly 1 million unique visitors [2], many outside of the United States.

The lasting impact of paradigm-changing platforms such as Open Access and MIT OCW remains to be quantified. On an anecdotal level, my impression from editing Retrovirology suggests that greater accessibility

Correspondence: kj7e@nih.gov

The National Institutes of Health, Bethesda, MD, USA does translate into more impact. For instance, I examined the most accessed Retrovirology papers over the past 12 months that were published in the preceding two years. Amongst the top nine most highly accessed original research articles, there are three papers which were published in either 2008 or 2009 [3-5]. These papers have been accessed over the past year 9675 , 4399, and 5909 times, respectively. Each is also in the $10 \%$ of highest cited Retrovirology papers of a similar vintage. Thus while papers need not be highly read in order to be highly cited (e.g. review articles $[6,7]$ are highly cited without necessarily being highly accessed), a large proportion of well cited papers is made up of those articles that are the most frequently read.

The gratification from editing Retrovirology is the realization that Open Access and other similar information distribution initiatives are doing well by doing good.

\section{Acknowledgements}

The opinions expressed are the author's personal views and do not necessarily reflect those of his employer, the National Institutes of Health $(\mathrm{NIH})$. Work in KTJ's laboratory is supported in part by intramural funding from the National Institute of Allergy and Infectious Diseases (NIAID). The author thanks Mark Wainberg for a critical reading of this editorial.

Received: 10 August 2010 Accepted: 13 August 2010

Published: 13 August 2010

\section{References}

1. Jeang KT: The Retrovirology Open Access experience. Retrovirology 2009, 6:115.

2. d'Oliveira C, Carson S, James K, Lazarus J: SPORE series winner. MIT OpenCourseWare: unlocking knowledge, empowering minds. Science 2010, 329:525-526.

3. Humbert M, Rasmussen RA, Song R, Ong H, Sharma P, Chenine AL, Kramer VG, Siddappa NB, Xu W, Else JG, Novembre FJ, Strobert E, O'Neil SP, Ruprecht RM: SHIV-1157i and passaged progeny viruses encoding R5 HIV-1 clade C env cause AIDS in rhesus monkeys. Retrovirology 2008, 5:94.

4. Andrew AJ, Miyagi E, Kao S, Strebel K: The formation of cysteine-linked dimers of BST-2/tetherin is important for inhibition of HIV-1 virus release but not for sensitivity to Vpu. Retrovirology 2009, 6:80. 
5. Hohn O, Krause H, Barbarotto P, Niederstadt L, Beimforde N, Denner J, Miller K, Kurth R, Bannert N: Lack of evidence for xenotropic murine leukemia virus-related virus (XMRV) in German prostate cancer patients. Retrovirology 2009, 6:92.

6. Goila-Gaur R, Strebel K: HIV-I Vif, APOBEC, and intrinsic immunity. Retrovirology 2008, 5.

7. Foster JL, Garcia JV: HIV-1 Nef: at the crossroads. Retrovirology 2008, 5.

doi:10.1186/1742-4690-7-67

Cite this article as: Jeang: Intelligence and ambition are distributed equally around the globe. Retrovirology 2010 7:67.

Submit your next manuscript to BioMed Central and take full advantage of:

- Convenient online submission

- Thorough peer review

- No space constraints or color figure charges

- Immediate publication on acceptance

- Inclusion in PubMed, CAS, Scopus and Google Scholar

- Research which is freely available for redistribution

Submit your manuscript at www.biomedcentral.com/submit 